\title{
ECONOMIC ANALYSIS OF LAND MANAGEMENT PRACTICES AMONG CROP FARMERS IN OSUN STATE, NIGERIA
}

\author{
${ }^{*}$ Ezekiel, A. A., ${ }^{2}$ Ayinde, E.O. and ${ }^{2}$ Akinsola, G.O. \\ 1Department of Agricultural Economics, Ladoke Akintola University of Technology, \\ Ogbomosho, Nigeria \\ 2Department of Agricultural Economics and Farm Management, University of llorin, Ilorin, \\ Nigeria \\ *Corresponding Author: aaezekiel@lautech.edu.ng
}

\begin{abstract}
Increase in soil degradation has negatively impacted on food production. This therefore necessitates sound land management practices. This study analyzed the economics of the land management practices among crop farmers in Osun State, Nigeria. Data were collected with the aid of structured interview schedule from 80 respondents in four Local Government Areas of the state using a three-stage sampling techniques. Budgetary and multiple regression analyses were the analytical tools employed. About $63 \%$ of the farmers were male and $78.4 \%$ of them were above 38 years. Seventy-two percent of the farmers had secondary sources of income. The average gross margin of the farms was $\$ 48,456.56 \mathrm{k}$. The total value product increases by a value of $A 4.90 \mathrm{~K}$ for every $\mathrm{A} 1$ increase in the total variable cost. The study concludes that land management practices such as fertilizer application, length of fallow on land and length of tillage on land have a positive effect on crop output in the study area. Therefore, extension services should be intensified to disseminate modern ideas and technology in crop farming for greater productivity. Activities that promote soil tillage for crop production should be encouraged as this would increase crop output.
\end{abstract}

Keywords: Economic analysis, Land management, Fallowing, Crop output 


\section{INTRODUCTION}

The contribution of agriculture to the Nigerian Gross Domestic Product (GDP) cannot be under-estimated. Of all the four sub-activities that make up the sector (crop production, livestock, forestry, and fishing), crop production remains the major driver of the sector, accounting for $89.84 \%$ of nominal agriculture GDP \{National Bureau of Statistics (NBS), $2019\}$. In the third quarter of 2017 , the contribution of agriculture to nominal GDP was $24.44 \%$ (NBS, 2017), indicating a marginal rise from 23.86 percent in the fourth quarter of 2014 \{Central Bank of Nigeria (CBN), 2016\}. It is noteworthy that agriculture has not reached its highest potential due to inherent constraints. One of these is the degraded form of soil fertility, resulting in nutrient deficiency, low organic matter, moisture stress, and high erosion.

According to Winslow et al. (2011), sustainable land management practices entail the longterm conservation of the ecological unit and establishment of biome services desired by people. This was defined by the World Overview of Conservation Approaches and Technologies (WOCAT) (2007) as the use of land assets in producing goods and services that satisfy changing human essentials while concurrently ensuring the long-standing availability of land resources with productive potential. Continuous cultivation leads to the reduction of humus in the soil. Human activities have grossly caused soil degradation and productivity of soils has been debar through natural forces, leading to a damaged ecosystem (Ifabiyi, 2004). Effective and economically feasible management practices are, therefore, needed to prevent soil degradation (USDA, 2001). Managing and enhancing the condition of soil environment is a veritable tool to enhance increased agricultural productivity. This determines the worth of bio-network amenities provided to the agricultural lands, preserves biodiversity and sustains the resilience of agricultural activities to climate variability. Land management practices involve ways by which farmers can raise yields and production to the required levels. Much more important is the management of the soils and water resources and improved cropping practices in developing countries. All these help agriculture in keeping pace with the world population and its rising demand for food. This study, therefore, examines the land management practices and their effects on crop production in Osun State, Nigeria.

\section{METHODOLOGY}

\section{Study Area}

This study was conducted in Osun State, Nigeria. The state is situated in the tropical rain forest zone. It covers an area of approximately $14,875 \mathrm{sq} \mathrm{km}$ and lies between latitude $7^{\circ} 30^{\prime} \mathrm{N}$ and longitude $4^{\circ} 30^{\prime} \mathrm{E}$. Though a landlocked state, it is blessed with presence of many rivers and streams which serves the water needs of the state. It is bounded by Ogun State to the south, Kwara State to the north, Oyo State to the west and Ekiti and 
Ondo State to the east. The state is within the tropical rain forest with abundance of resources. Mineral resources found in the state include gold, kaolin and others which are being extracted for the benefit of the state and the people. The state is widely known for the production of arable and cash crops (Osun state official website, 2020).

\section{Sampling Procedure and Sample Size}

A three-stage sampling technique was used in the study to select the respondents for the study. At the first stage, four Local Government Areas were selected. These were Atakumosa East, Atakumosa West, Aiyedaade and Aiyedire. The second stage involved the selection of five villages in each of the LGAs, making a total of 20 villages. The third stage involved the random selection of four respondents from each village. This summed up to 80 respondents.

\section{Method of Data Collection}

Data collection was done using a structured schedule through personal interview.

\section{Data Analysis}

The tools used for the data analyses were descriptive statistics, farm budgetary technique and the logit regression analysis. Simple descriptive analysis was used to describe the demographic characteristics of the respondents as well as the level of use of various land management practices by the respondents. Farm budgetary technique was employed to estimate the profitability of farm enterprise by the respondents. Multiple Logit regression analysis was used to examine the effect of land management practices on crop production.

Following the works of Abbott and Makeham (1990) and Erhabor and Olukosi (1987), budgetary analysis was used to estimate the costs and returns of the crop farms in the study are and to determine the profitability of their production enterprise. This involved estimation of the variable costs, fixed costs, total cost, gross margin and net profit. Fixed cost is the total outlay which remains constant irrespective of changes in output level. Fixed cost refers to the cost of physical asset while the variable cost covers the expenses which range directly in size positively with variation in output level and production level. It is the cost incurred on various inputs used for production. Abbott and Makeham (1980) define gross margin as the difference between the total income or revenue and the total variable cost incurred by the farmers. The difference between the total revenue and the total variable cost of production is referred to as gross margin (Erhabor and Olukosi 1987). Net profit margin was defined as the difference between the gross margin and the depreciation.

$\mathrm{GM}=\mathrm{TR}-\mathrm{TVC}$

$T C=T V C+T F C$ 
$\mathrm{NM}=\mathrm{TR}-\mathrm{TC}$

Where TR is the total revenue; TVC is the total variable cost; TFC is the total fixed cost; TC is the total cost incurred and NM is the net margin.

A multiple regression technique was used to establish the exogenous variables determining the endogenous variable. The relevant relationship was established between the total output of crop ( $s$ ) and the land management practices.

as: $Q=f(X, R, D)$

Where:

$Q=$ Output (grain equivalent)

$X=$ Vector of physical inputs

$D=$ Vector of land management practices

$\mathrm{R}=$ Vector of parameter estimates

$Q$ explicitly implies:

$\ln Q=\alpha_{1}+\alpha_{2} \ln x_{2}+\alpha_{3} \ln x_{3}+\alpha_{4} \ln x_{4}+\alpha_{5} \ln x_{5}+\alpha_{6} \ln D_{2}+\alpha_{7} \ln x_{1} \ln x_{2}+\alpha_{8} \ln x_{1} \ln x_{5}+\alpha_{9} \ln x_{1} \ln D_{1}+$ $U$

Where:

$X_{1}=$ Farm size (hectares)

$X_{2}=$ Labour (man-day)

$\mathrm{X}_{3}=$ Herbicides (litres)

$X_{4}=$ Cost of planting materials

$X_{5}=$ Fertilizer $(\mathrm{kg})$

$D_{1}=$ Practice of tillage (dummy) (by considered those farmers that practiced tillage as 1 and non-practice tillage as 0 ) tillage mean land cultivation

$D_{2}=$ Practice of bush fallowing (dummy)

\section{RESULTS AND DISCUSSION}

\section{Socio-economic Characteristics of the Farmers}

The result shows that $63.4 \%$ of the respondents were male, while $36.6 \%$ were females. This implies that farming is a male-dominated activity in the study area. The majority of the farmers were within the age of $31-40$ years. The major occupation of the majority of the farmers was farming. About $45 \%$ of the farmers had more than a farmland. This implies that such farmers could practice bush fallowing. About $87 \%$ of the farmers produced food crops. The results further show that only $19.4 \%$ of the farmers used tractor. This suggests that the majority of the farmers did not practice mechanized farming. However, the fact that most of the farmers did not use tractor had the tendency of reducing the rate of soil compaction on 
their farms, thus enhancing aeration. At least, $50 \%$ of the farmers have been in farming for more than 10 years.

Table 1: Socio-economic characteristics of the farmers $(n=80)$

\begin{tabular}{|c|c|c|}
\hline Variables & Frequency & Percentage \\
\hline \multicolumn{3}{|l|}{ Sex } \\
\hline Male & 50 & 63.4 \\
\hline Female & 30 & 36.6 \\
\hline \multicolumn{3}{|l|}{ Age (Years) } \\
\hline$<30$ & 2 & 2.5 \\
\hline $30-40$ & 16 & 58.4 \\
\hline $41-50$ & 29 & 16.1 \\
\hline $51-60$ & 29 & 17.0 \\
\hline $61-70$ & 4 & 5.0 \\
\hline \multicolumn{3}{|l|}{ Marital status } \\
\hline Single & 14 & 17.5 \\
\hline Married & 65 & 81.25 \\
\hline Separated & 1 & 1.25 \\
\hline \multicolumn{3}{|l|}{ Household size } \\
\hline $1-5$ & 62 & 77.5 \\
\hline $6-10$ & 18 & 22.8 \\
\hline \multicolumn{3}{|l|}{ Education } \\
\hline No formal education & 10 & 12.50 \\
\hline Primary education & 26 & 32.75 \\
\hline Secondary education & 29 & 36.25 \\
\hline Tertiary education & 14 & 17.50 \\
\hline Adult education & 1 & 1.25 \\
\hline \multicolumn{3}{|l|}{ Primary occupation } \\
\hline Farming & 59 & 72.0 \\
\hline Other businesses & 21 & 28.0 \\
\hline \multicolumn{3}{|l|}{ *Farm Characteristics } \\
\hline Have more than a farmland & 40 & 45.2 \\
\hline Farmers producing food crops & 61 & 87.1 \\
\hline Farmers using tractor & 10 & 19.4 \\
\hline \multicolumn{3}{|l|}{ Experience (Years) } \\
\hline$<10$ & 40 & 50.0 \\
\hline $11-20$ & 23 & 28.75 \\
\hline $21-30$ & 14 & 17.5 \\
\hline $31-40$ & 3 & 3.0 \\
\hline
\end{tabular}

*Multiple responses allowed; Source: Field survey, 2018. 


\section{Land Management Practices Employed by the Respondents}

Table 2 shows the land management practices carried out by the respondents. The land management practices identified in the study area include tillage, bush fallowing, and fertilizer application. Some farmers used only one management method while others combined them. From the study, few farmers practiced bush fallowing and tillage. The majority (62.5\%) of the farmers practiced fertilizer application. Meanwhile, 12.5\% combined various land management practices. Tillage may impact crop production for future use of land. As regards the frequency of tillage, the implication is the fast removal of soil top layer nutrients and disturbance of bio-life.

Table 2: Land Management Practices Employed by the Respondents

\begin{tabular}{lll}
\hline Land Management Practices & Frequency & Percentage \\
\hline Fertilizer application & 50 & 62.5 \\
Buh fallow & 10 & 12.5 \\
Tillage & 10 & 12.5 \\
Combine Land Management Practices & 10 & 12.5 \\
\hline
\end{tabular}

Source: Field survey, 2018.

\section{Profitability of Crop Production in the Study Area}

Table 3 summarizes the costs and returns to crop production by the respondents. A total variable cost of $A 65440.21$ was incurred the farmers per hectare. This cost covered the costs of labour, planting materials, chemicals (fertilizer, pesticides, herbicide and insecticides) and transportation. These costs account for $80.77 \%$ of the total cost of production. A total fixed cost of 15632.37 was incurred by the farmers per hectare. This accounted for $19.28 \%$ of the total cost of production. This cost covered rent and depreciation on the farm equipment owned by the farmers. Such equipment include watering can, sprayer and rake, among others. These give a total cost of $A 81072.58$ per hectare. Thus, the farmers had a gross margin and net profit of $A 48456.56 /$ ha and $A 43456.56 /$ ha respectively. This results show that crop production is a profitable venture in the study area.

Table 3: Analysis of costs and returns to crop farming

\begin{tabular}{ll}
\hline Variables & /ha \\
\hline Variable Cost & 65440.21 \\
Fixed Cost & 15632.37 \\
Total Cost & 81072.58 \\
Total Revenue & 124529.14 \\
Gross Margin & 48456.56 \\
Net profit & 43456.56 \\
\hline
\end{tabular}

Source: Field survey, 2018. 


\section{Factors Influencing Crop Output in the Study Area}

The result of the regression analysis on the factors influencing crop output in the study area is shown in Table 4. The result shows that the coefficient of multiple determinations $\left(R^{2}\right)$ was $71.4 \%$. This implies that $71.4 \%$ of the total variation in the farmers' crop output is explained by variation in the independent variables included in the model. These independent variables are: $X_{1}$ (cost of land), $X_{2}$ (cost of labour), $X_{3}$ (capital/fixed cost), $X_{4}$ (cost of materials/inputs\}, $X_{5}$ (length of fallow\}, $D_{1}\{$ length of tillage $\}$ and $D_{2}$ (fertilizer application\}.

Table 4: Determinants of crop output in the study area

\begin{tabular}{llll}
\hline & Coefficient & Standard error & t-Value \\
\hline Constant & 37406.665 & 118118.18 & 0.317 \\
$X_{1} X_{5}$ (land, length of fallow) & 40.059 & 50.392 & 0.795 \\
$X_{1} X_{2}$ (land, labour) & $9.986^{* *}$ & 30.499 & 3.327 \\
$X_{1} D_{1}$ (land, length of tillage) & $11.167^{* *}$ & 15.281 & 1.931 \\
$X_{3}$ (Capital) & 0.994 & 1.324 & 0.750 \\
$X_{4}$ (cost of planting materials) & $4.934^{* *}$ & 5.119 & 3.964 \\
$X_{2}$ (labour) & -24.206 & 25.874 & -0.936 \\
$D_{2}$ (fertilizer) & $-4336.073^{* *}$ & 49176.971 & -4.088 \\
$X_{5}$ (length of fallow) & -37587.138 & 48991.518 & -0.767
\end{tabular}

Source: Field Data, 2018.

Adjusted $\mathrm{R}^{2}=0.714 ;$ F-value $=0.313$

Note: $5 \%$ level of significance $(<0.05)=\left({ }^{* *}\right)$

$\log Q=\log (37406.665)+(-24.206) \log x_{2}+(0.994) \log x_{3}$

$$
\begin{array}{ccc}
0.317 & -0.936 & 0.750 \\
+(4.934) \log x_{4}+ & (-37587.139) \log x_{5}+ & (-4336.073) \mathrm{D}_{2} \\
3.964^{*} & -0.767 & -4.088^{*} \\
+(9.986) \log x_{1 \times 2}+ & (40.059) \log { }_{1} 1 x_{5}+(11.167) \log x, D,+U \\
3.327^{*} & 0.795 & 1.931^{* *}
\end{array}
$$

Table 4 indicates that fertilizer application $\left(D_{2}\right)$ has an inverse relationship with the output. This implies that the marginal physical productivity MPP has fallen. Also, $X_{3}$ is positive, and this implies that there is a positive relationship between fixed capital and output $Q$. This could be because the MPP increases when fixed capital increases and therefore an increase in output $Q$. Cost of inputs $\left(X_{4}\right)$ had a positive value, and their increase brought about an increase in total output in the study area. This suggests that rather than for farmers to increase spending on fertilizers, more should be spent on other chemicals to stop the 
invasion of pest and disease. The total value product increases by a value of $\mathrm{A4} .90 \mathrm{k}$ for every 1 increase in the total variable cost $\left(X_{4}\right)$.

Therefore, this has a direct relationship with output $Q$. This implies that more land demands

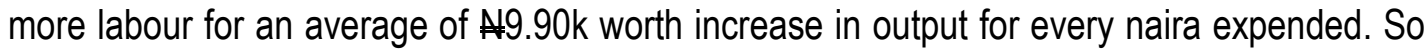
also the estimated coefficients of the length of fallow on land $\left(X_{1} X_{5}\right)$, shows that for every year

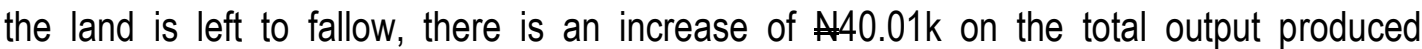
compared to that of untilled land. The effect of length of tillage on land is significant at the $10 \%$ probability level.

\section{CONCLUSION AND RECOMMENDATIONS}

This study was carried out to analyze land management practices in crop production in Osun State, Nigeria. This is needed to improve food security and make Nigeria a net exporter of food. The study concluded on the premise that land management practices such as fertilizer application, length of fallow on land and length of tillage on land exhibit positive effect on crop output. Therefore, extension services should be intensified to disseminate information on modern land management practices in crop farming for greater productivity among farmers. In the same vein, activities that promote soil tillage for crop production in the area should be encouraged as this would increase crop output.

\section{REFERENCES}

Abbott, J.C. and Makeham, J. P. (1990). Agricultural Economics and Marketing in the Tropics. pp 106. England: Longman group Ltd. Available online at https://trove.nla.gov.au/work/14206183

Ande, O.T., Adediran, J.A., Ayoola, O.T. and Akinlosotu, T.A. (2008). Effects of land quality, Management and cropping systems on cassava production in Southern Western Nigeria.African Journal of Biotechnology, 7(14), 2368 - 2374. Available online at https://www.ajol.info/index.php/ajb/article/view/59001

Central Bank of Nigeria (CBN), (2016). Annual Statistical Bulletin:Retrieved from https://www.cbn.gov.ng/documents/Statbulletin.asp

Erhabor P.O. and Olukosi J.O. (1987). Introduction to Farm Management Economics: Principles and Applications. Pp 79. Zaria. Agitab Publishers Ltd: Zaria.

Ifabiyi, I.P. (2004) Agricultural implication of subsurface flow in part of the basement complex of Northern Nigeria. Agrosearch, Nigeria. 6(1), 29-37. Available online at https://www.ajol.info/index.php/agrosh/article/view/116510 
National Bureau of Statistics (NBS), (2017). Nigerian Gross Domestic Product Report: pp 48. Available online at https://nigerianstat.gov.ng/elibrary

National Bureau of Statistics (NBS), (2019). Nigerian Gross Domestic Product Report: Available online at https://nigerianstat.gov.ng/elibrary

Osun State official website (2020). Available online at https://www.osunstate.gov.ng/mdas/geography

Winslow, M.S., Sommer, H., Bigas, C., Martius, J., Vogt, M., Akhtar-Schuster, and Thomas, R (2011). Understanding Desertification and Land Degradation Trends. In Proceedings of the UNCCD First Scientific Conference: 22-24.

Argentina: The UNCCD Ninth Conference of Parties, Bueno sires. Luxembourg: Office $f$ or Official Publications of the European Communities

WOCAT, World Overview of Conservation Approaches and Technologies. (2007). Where the Land Is Greener: Case Studies and Analysis of Soil and Water Conservation Initiatives Worldwide: 110 pp. U.S: Co published by CTA, UNEP, FAO and CDE. www.wocat.net/fileadmin/user_upload/documents/Books/WOOK_PART1.pdf . 